\title{
Koers and the ideal of Christian scholarship
}

\begin{abstract}
Author:
Daniël F.M. Strauss ${ }^{1}$

Affiliation:

${ }^{1}$ Department of Philosophy, University of the Free State, South Africa
\end{abstract}

\section{Correspondence to:}

Daniël Strauss

Email:

dfms@cknet.co.za

Postal address:

PO Box 339, Bloemfontein

9300 , South Africa

\section{Dates:}

Received: 05 July 2011

Accepted: 26 Oct. 2012

Published: 09 Nov. 2012

How to cite this article:

Strauss, D.F.M., 2012, 'Koers and the ideal of Christian scholarship', Koers - Bulletin for Christian Scholarship 77(1), Art. \#29, 9 pages. http://dx.doi.org/10.4102/ koers.v77i1.29

\section{Note:}

This article was developed from a paper delivered at the Koers-75 Conference on 'Worldview and Education', held in Potchefstroom, South Africa, from 30 May to 02 June 2011.

Hierdie artikel is ' $n$ verdere ontwikkeling van ' $n$ voordrag gelewer by die Koers-75 Konferensie oor 'Worldview and Education' in Potchefstroom, SuidAfrika, vanaf 30 Mei tot 02 Junie 2011.
C 2012. The Authors Licensee: AOSIS OpenJournals. This work is licensed under the Creative Commons Attribution License.
Commemorating the 75-year existence of the journal Koers is connected to the Reformational tradition, from Calvin to Kuyper, Stoker, Dooyeweerd and Vollenhoven - all thinkers who realised that the biblical starting point of life indeed touches the heart, the religious root, of humankind and therefore cannot remain restricted to church life and religion in its narrow sense, but must come to expression in all walks of life. This awareness was a fruit of the Christian worldview and lifeview which currently is confronted by the Big Bang claims and by neo-Darwinism - both movements taking on cultic dimensions with an intolerance towards everyone who does not accept their perspective. Their attitude generated serious reactions on two websites, the impact of which was discussed in this article. Some problems entailed in Darwinism and physicalistic materialism were highlighted, before attention was given to the status of natural laws and normative principles. Particular attention was given to the elimination of God's law and the way in which modern Humanism explored the two cornerstones of modern nominalism, up to the point where human understanding was elevated to become the a priori formal law-giver of nature. This legacy was continued both by the later developments within the Baden school of neo-Kantian thought and Postmodernism, which is placed within the context of the three succeeding epistemic ideals of the past three centuries. Rationality can only fulfil its true calling when it accounts for the cohering diversity within reality without becoming a victim of any form of reductionism - and by following this guiding star, Koers will continue to strengthen its invaluable contribution to the advancement of Christian scholarship.

Koers en die ideaal van Christelike wetenskap. Die 75-jarige herdenking van die bestaan van die tydskrif Koers is verbind aan die reformatoriese tradisie vanaf Calvyn tot by Kuyper, Stoker, Dooyeweerd en Vollenhoven, almal denkers wat besef het dat die Bybelse uitgangspunt van die lewe die hart as religieuse wortel van die mens se bestaan raak en daarom nie tot die sfeer van die kerk en godsdiens in enger sin beperk kan bly nie - dit moet inderdaad in alle sektore van die lewe deurwerk. Hierdie besef is die vrug van die Christelike lewens- en wêreldbeskouing wat tans gekonfronteer word deur die Big Bang-aansprake en deur die neo-Darwinisme - beide bewegings wat kulties-godsdienstige vorme aanneem en wat intolerant is teenoor elkeen wat nie hul perspektief aanvaar nie. Hierdie instelling het ernstige reaksie op twee webtuistes ontlok. Sommige probleme wat in die Darwinisme en die fisikalistiese materialisme vervat is word belig alvorens aandag aan die status van natuurwette en normatiewe beginsels gegee word. Besondere aandag word geskenk aan die eliminering van God se wet en aan die wyse waarop die moderne Humanisme twee van die grondpilare van die moderne nominalisme ontglip het, tot op die punt waar die menslike verstand tot die apriories-formele wetgewer van die natuur verhef is. Hierdie erfenis is gekontinueer beide deur die latere ontwikkelinge in die neo-Kantiaanse Badense skool en in die postmodernisme, geplaas teen die agtegrond van die drie opeenvolgende kennisideale van die afgelope drie eeue. Rasionaliteit kan slegs die ware roeping daarvan vervul indien dit rekenskap gee van die samehangende verskeidenheid in die skepping sonder om die slagoffer van enige vorm van reduksionisme te word. Wanneer Koers hierdie leidster volg sal dit daarmee voortgaan om 'n waardevolle en onmisbare bydrae te bly lewer ten bate van die bevordering van Christelike wetenskap.

\section{Introduction}

Commemorating the 75-year existence of the journal Koers most certainly deserved a special conference. The request to respond at the end of this conference enabled an overview of the presentations and discussions that took place during the Conference and it also once more invited a reflection on the central ideal of Christian scholarship and the place of our Christian worldview in it - focused on the ultimate concern for advancing scholarship from the perspective of a nonreductionist ontology (as will be explained below). 
By the end of the 19th century, Kuyper realised that the Reformation of the 16th century had indeed touched the heart, the religious root, of humankind and therefore could not remain restricted to church life and religion in its narrow sense, but must come to expression in all walks of life. This realisation emerged within the immediacy of everyday life and the threat which the idea of an objective and neutral scholarship entailed for the freedom of Christians within the academic world. Establishing the Vrije Universiteit in Amsterdam in 1880 was therefore a fruit of the Christian life and worldview - the ideal of Christian scholarship did not derive from scholarship itself but from the non-theoretical starting point of the Christian life and worldview. Kuyper aimed to create a university free from the interference of both Church and State. At the moment, Western culture experiences once more a situation in which the Christian life and worldview is threatened by non-Christian orientations.

Within the sphere of public opinion, largely informed by newspapers, popular magazines and journals and, of course, television, we are currently once again confronted with a worldview which challenges Christians in the name of scholarship and solid science. The Big Bang theory pretends to 'solve' the mystery of creation by means of a physical theory and neo-Darwinism dominates the public sphere with its pretended scientific (biological) approach to an understanding of the world. These realities call Christians to respond with intellectual integrity and scholarly expertise.

Accomplishing this task inevitably encompasses an account of the place and nature of humankind within the universe and, of necessity, it leads us to consider boundary questions that are directed at the ultimate horizon of our experience of the universe. Creaturely reality is not self-sufficient, it is not autonomous or independent, because every creature is fitted in an unbreakable coherence with other creatures. This insight accounts for the relativity of creaturely reality without falling prey to an unbridled relativism. This relativity rather accentuates the relatedness of creatures, the coherence of everything with everything else. Yet coherence is just the one side of the coin - uniqueness constitutes the other side. And uniqueness is dependent upon demarcation and delimitation which, in turn, manifests the determining role of creational laws - also setting limits to what we can experience. The creaturely mode of existence is one of being subjected to God's determining and delimiting laws. In a similar manner to the way in which the horizon of our visual field constitutes the limit of what we can see, the contours of God's law constitute the ultimate horizon of human experience.

Insofar as these questions concern the limits of our experience, various academic disciplines pretended to be able to provide the ultimate answers at stake. Traditionally, theology fulfilled a prominent role in this regard, but with the emancipation of rationality since the Renaissance, mathematics and mathematical physics increasingly assumed an equally notable role, particularly since the rise of the Big Bang theory.
And, even earlier, since 1859, certain trends of thought in biology and related disciplines increasingly believed that the natural sciences can account for everything - from atoms and molecules up to human beings. Already during the 1960s of the previous century, the biochemist Jevons (1964:97) wrote: 'The continuity of the hierarchy offers hope that by systematic, step by step comparisons the gap between molecules and large animals can be bridged.' Almost two decades later, a book appeared with the title: Evolution from molecules to men (see ed. Bendall 1983).

Two significant reactions have also recently emerged. Firstly, the New Scientist magazine (2004) published a collective statement from 405 natural (physical science) scientists in the field of physics and related disciplines under the title: 'An open letter to the scientific community.' The scientists commence their reaction with the following paragraph:

The big bang today relies on a growing number of hypothetical entities, things that we have never observed - inflation, dark matter and dark energy are the most prominent examples. Without them, there would be a fatal contradiction between the observations made by astronomers and the predictions of the big bang theory. In no other field of physics would this continual recourse to new hypothetical objects be accepted as a way of bridging the gap between theory and observation. It would, at the least, raise serious questions about the validity of the underlying theory. (2004:para. 1)

Furthermore, they advance substantial scientific concerns, including complaining about the intolerance of differences of opinion, publications and research funding.

Secondly, a website with the name $A$ scientific dissent from Darwinism (http://www.dissentfromdarwin.org/) 12 June 2011 states:

We are skeptical of claims for the ability of random mutation and natural selection to account for the complexity of life. Careful examination of the evidence for Darwinian theory should be encouraged. (Discovery Institute 2008)

In a similar manner to the New Scientist argument, the fourth point in a list of frequently asked questions (FAQ) on this website, reads:

In recent years there has been a concerted effort on the part of some supporters of modern Darwinian theory to deny the existence of scientific critics of Neo-Darwinism and to discourage open discussion of the scientific evidence for and against NeoDarwinism. The Scientific Dissent From Darwinism statement exists to correct the public record by showing that there are scientists who support an open examination of the evidence relating to modern Darwinian theory and who question whether Neo-Darwinism can satisfactorily explain the complexity and diversity of the natural world. (Discovery Institute 2008)

The last FAQ listed is, 'Are there credible scientists who doubt Neo-Darwinism?' Their answer reads:

1.They say that 'in cosmology today doubt and dissent are not tolerated, and young scientists learn to remain silent if they have something negative to say about the scientists learn to remain silent if they have something negative to say about the standard big bang model. Those who doubt the big bang fear that saying so will cost them their funding... Today, virtually all financial and experimental resources in cosmology are devoted to big bang studies. Funding comes from only a few sources, and all the peer-review committees that control them are dominated by supporter of the big bang. As a result, the dominance of the big bang within the field has become self-sustaining, irrespective of the scientific validity of the theory' (New Scientist 2004:paras. 6, 8). 
Yes. Signers of the Scientific Dissent From Darwinism hold doctorates in biological sciences, physics, chemistry, mathematics, medicine, computer science, and related disciplines from such institutions as Oxford, Cambridge, Harvard, Dartmouth, Rutgers, University of Chicago, Stanford and University of California at Berkeley. Many are also professors or researchers at major universities and research institutions such as Cambridge, Princeton, MIT, UCLA, University of Pennsylvania, University of Georgia, Tulane, Moscow State University, Chitose Institute of Science \& Technology in Japan, and Ben-Gurion University in Israel. (Discovery Institute 2008)

Apart from these dissenting voices within the current situation of these disciplines, it should be remembered that 20th century physics includes classical determinism (Bohm, Einstein, Schrödinger and the school of De Broglie), the mechanistic main tendency of classical physics (last represented by Heinrich Hertz) and the Copenhagen interpretation of quantum mechanics (Bohr and Heisenberg). Likewise, 20th century biology diverges into distinct and mutually exclusive schools of thought. Just consider the mechanistic orientation (Eisenstein), the physicalistic approach (neo-Darwinism), neo-vitalism (Driesch, Haas, Heitler, Rainer Schubert-Soldern, Sinnott - continued in recent theories of complexity and intelligent design), holism (Adolf Meyer-Abich and Jan Smuts), emergence evolutionism (Bavinck, Lloyd-Morgan, Polanyi, Woltereck) and pan-psychism (Teilhard de Chardin, Bernard Rensch).

Referring to these facts is important because it demonstrates the (abovementioned) relativity of scholarly endeavours even within the natural sciences. Merely studying the history of any discipline irrevocably challenges the pretentions of 'universal reason'.

\section{Some crucial problems entailed in neo-Darwinism}

Darwin did not attempt to give an account of the origination of the first living entities. At the end of his Origin of Species he actually used the kind of language found in the longstanding vitalistic tradition within biology, dating back to Aristotle. According to vitalism, 'life' is an immaterial force acting upon lifeless matter. Darwin ([1859a] 1968:459-460) wrote: 'There is grandeur in this view of life, with its several powers, having been originally breathed by the Creator into a few forms or into one.' The constantly increasing natural scientific knowledge regarding the complexity of the smallest living entities makes it all the more difficult to provide a rational account of the supposed origination of living entities. Whilst Darwin still reverted (inconsistently) to a 'life-breathing' Creator, present-day neo-Darwinists, for the sake of their physicalistic starting point, simply proceed from the assumption that living entities indeed 'evolved' from non-living material configurations, most probably 'selfduplicating' molecules. Any subsequent attempt to explain the transition from the non-living to the living then becomes circular, because the ultimate conviction is already in place: living things did in fact evolve from non-living things. Such a position is illogical because it begs the question. It is a good example of a petitio principii where one accepts as a given what one wants to demonstrate.

Initially, the emphasis was on the so-called 'building blocks' of living things, directed at DNA molecules, and soon it was clear that the 'hardware' needs the 'software', the information (entailed in the genetic code). Yet, the random origination of this information runs into serious statistical problems, apart from the fact that DNA and protein mutually presuppose each other.

Furthermore, we know that the 20 different amino acids serve as the basis for multiple enzymes responsible for catalysing reactions in the various metabolic pathways within the cell (there can be up to 100000 enzymes in a single cell). One such an enzyme, phosphatase, catalyses reactions taking place in a hundredth of a second - reactions that otherwise (in the absence of this enzyme) would take a trillion years (see Lang 2003; Sarfati 2010:241).

Adenosine triphosphate (ATP - the energy currency of the cell as it is also called) synthase is the smallest motor in the world. Sarfati (2010) remarks:

This motor is unique in that it uses electricity to turn a rotor, which squeezes two components of ATP (ADP and phosphate) at high enough energy to form ATP. Then it throws off the ATP and prepares to accept new ADP and phosphate. This motor turns at about 10,000 revolutions per minute, and each rotation produces three ATP molecules. (p. 242)

Attempting to explain the origination of this motor, viewed as the result of random interactions between atoms and molecules, exceeds all odds. It is undoubtedly an instance of a complex biotic motor (organ) that cannot be explained in terms of incremental, slight changes, sufficient to answer to a condition according to which Darwin's whole theory would break down. Darwin (1859b:109) wrote: 'If it could be demonstrated that any complex organ existed, which could not possibly have been formed by numerous, successive, slight modifications, my theory would absolutely break down.' Perhaps the most amazing feature of these little motors is that there are so many of them within the human body. Using many trillions of these motors, the human body generates every day ATP equivalent to the mass of the human body (see Sarfati 2010:242).

\section{Darwin's ambiguous position regarding progress}

Darwin truncated the term 'evolution' by eliminating its inherent biotic connotations. With the rise of an investigation of the physical-chemical substrate of living entities, this legacy supported the newly introduced terminology, for natural scientists started to speak of 'molecular biology'. From the perspective of his organismic biology, Von Bertalanffy (1973) reacted by emphasising the difference between atoms, molecules and macromolecules on the one hand and living entities on the other. Because molecules, as such, are not alive, they cannot display vital properties such as being healthy, 
ill or dying. From a thermodynamic (physical) perspective, the cell prevails in a state of the highest improbability. When the physical-chemical basis (substratum) of living things approaches a state of higher statistical probability (equilibrium), the increase of biotical instability anticipates the ultimate biotic process of dying. Von Bertalanffy (1973) radically rejects all reductionistic attempts aimed at an elimination of the biotic aspect of reality when it comes to an appreciation of the vital functioning (vital processes) of living entities:

These processes, it is true, are different in a living, sick or dead dog; but the laws of physics do not tell a difference, they are not interested in whether dogs are alive or dead. This remains the same even if we take into account the latest results of molecular biology. One DNA molecule, protein, enzyme or hormonal process is as good as another; each is determined by physical and chemical laws, none is better, healthier or more normal than the other. (p. 146)

Gould (1996:139) mentions that whilst natural selection talks only about 'adaptation to changing local environments' it does not include any 'statement whatever about progress'. Nor 'could any such claim be advanced from the principle of natural selection'. Analogous to what Von Bertalanffy said, Gould (1996) explains:

The woolly mammoth is not a cosmically better or generally superior elephant. Its only 'improvement' is entirely local; the woolly mammoth is better in cold climates (but its minimally hairy ancestor remains superior in warmer climates). Natural selection can only produce adaptation to immediately surrounding (and changing) environments. No feature of such local adaptation should yield any expectation of general progress (however such a vague term be defined). Local adaptation may as well lead to anatomical simplification as to greater complexity. (p. 139)

Acknowledging merely immediate fit provided no grounds for 'increments of general progress or complexification' and Gould (1996:140) appreciates Darwin in this regard as an intellectual radical who has a vision of the 'history of life devoid of predictable progress' - but this 'proved too much for his Western compatriots to accept'. Although politically liberal, Darwin was comfortably settled in a conservative segment of British society. According to Gould, this is the only explanation for the hybrid nature of Darwin's claims, for upholding on the one hand that natural selection inherently does not contain any bias towards progress and, at the same time, speaking of progress towards perfection on the other, is simply contradictory - being at once 'the intellectual radical and the cultural conservative' (Gould 1996:145). And:

moreover, Darwin enjoyed this comfort in a society that, more than any other in human history, had enshrined progress as the fundamental doctrine of its meaning and being-Victorian Britain at the height of industrial and colonial expansion. How could a patrician Englishman, at the very apex of his nation's thundering success, abjure the principle that embodied this triumph? And yet, natural selection could produce only local adaptation, not general progress. (p. 140-141)

What Gould did not consider in this context is that Darwin's a priori commitment to the continuity postulate of modern (humanistic) philosophy in a subtle way provided him with the trust (certainty) that although natural selection does not spell progress, the fossil record will fill the gap(s!). Unfortunately, it was precisely the dominance of gaps in the fossil record that contradicted his expectations and predictions, as well as the current discontinuous state of the world of living entities (sometimes designated as the Natural System). His firm belief was that 'natural selection acts solely by accumulating slight, successive, favourable variations', in line with the canon 'Natura non facit saltum' [Nature does not make jumps] (Darwin [1859a] 1968:307).

He applied this faith in the continuity of descent (and its instantiation in natural selection) to the fossil record and paleontological findings - just look at his explicit statement:

But just in proportion as this process of extermination has acted on an enormous scale, so must the number of intermediate varieties, which have formerly existed, be truly enormous. Why then is not every geological formation and every stratum full of such intermediate links? Geology assuredly does not reveal any such finely-graduated organic chain; and this, perhaps, is the most obvious and serious objection which can be urged against the theory. (Darwin [1859a] 1968:196)

At this point we may return to the abovementioned words of Darwin: 'There is grandeur in this view of life, with its several powers, having been originally breathed by the Creator into a few forms or into one' (Darwin [1859a] 1968:459-460). We have noted that, in addition, Darwin's (inconsistent) view also reflects the 18th century ideal of progress (and perfection) which prevailed in the conservative layer of British society within which Darwin found himself: 'And as natural selection works solely by and for the good of each being, all corporeal and mental endowments will tend to progress towards perfection' (Darwin [1859a] 1968:459).

\section{The impasse of a physicalist materialism}

Roy Clouser (2006:35) explains that for the materialist 'reality is ultimately physical, so that everything is either matter or dependent upon matter'. A strange instance of such an orientation is found in a recent work of Stephen Hawking (2010), who claims:

Because there is a law such as gravity, the universe can and will create itself from nothing. Spontaneous creation is the reason there is something rather than nothing, why the universe exists, why we exist. (Hawking \& Mlodinow 2010)

The well-known formulation of Newton's law of gravity states that the force of gravity $\mathrm{F}$ is directly proportional to the product of the masses of the attracting bodies $\left(m_{1}\right.$ and $m_{2}$ ) and indirectly proportional to the square of the distance between them $\left(r^{2}-\right.$ with $\mathrm{G}$ as a constant). Of course, we have to note that a law is not something independent, because it is fitted within the context of other laws and it is correlated to what is subject to it as a law. Reifying the law of gravity to the level of an independent origin of the universe breaks 
apart its intrinsic coherence with the diversity of creation and with those creatures subject to it - and in doing this it strips such an isolated law from its meaning. But apart from the presupposed correlation between law and subject, any law formulation therefore always presupposes more than the physical aspect of reality. Mass, for example, is a physical quantity whilst distance reflects the meaning of space. The idea of a constant cannot be conceived apart from the kinematic aspect with its core meaning of uniform flow (constancy). Finally, the concept force is derived from the physical aspect. In other words, the formulation of the law of gravity brings to expression the unbreakable coherence between the physical aspect and those non-physical aspects lying at its foundation within the order of creation.

Moreover, the materialist has to face other serious problems. If everything is material, then nothing material can exist, because the conditions making the existence of material things possible are not themselves material and are therefore non-existent. The conditions for being material are not material. Furthermore, the statement that everything is material pretends to be true. But truth is not material, for which are the atoms and molecules constituting the truth of the basic statement of materialism? The same applies to any falsehood.

The status of (physical) laws presents itself as the Achilles' heel of materialistic physicalism, because the conditions for the existence of something cannot be derived from that which meets these conditions. The conditions for being an atom are not themselves an atom, just as little as the conditions for being green are themselves green. The boundary process of the Big Bang is described in spatial ('dense') and physical ('heat') terms which presuppose physical and spatial laws. The abovementioned alternative recently proposed by Hawking, namely that the law of gravity will create the universe, acknowledges an element of the dilemma contained in the idea that what meets or conforms to a law could be seen as the source of the law. Yet, Hawking simply reverted to an equally objectionable position by elevating the law itself to become the origin of what is subjected to it. Acknowledging the correlation of law and subject does not entail that either could be deduced from the other.

From our brief analysis of the law of gravity it is also clear that no single kind of law 'stands on its own' for the physical aspect of reality presupposes the aspects of number, space and movement, each with their own unique laws. In fact the meaning of the physical aspect is constituted by its interconnections with non-physical aspects. For example, the first main law of thermodynamics, traditionally designated as the law of energy conservation, should actually be called the law of energy constancy, which is a kinematic retrocipation (backward-pointing analogy) to the original meaning of the kinematic aspect of uniform (constant) motion.

\section{From natural laws to norming principles}

In distinction from natural laws, human life is ruled by norming laws, known as principles (or norms). On the basis of logical principles, scholarly activities are concerned with distinguishing between truth and what is false. This distinction presupposes an accountable free will, enabling responsible decisions. Therefore the crucial question here concerns the status of normativity. Although we may differ about what is legal and illegal, polite and impolite, frugal and wasteful, and so on, it cannot be denied that in these oppositions we meet logical contraries. Once normativity, in this sense, is acknowledged one can account both for normconformative and antinormative human actions.

This normativity of life underlies the mystery of sin - through which the possibility of disobeying God became an actuality. Because illogical thinking is still a form of thinking, namely antinormative thinking, we cannot escape from the God-given ordinances, because also in Christ is the order for logical (and illogical) thinking maintained. Without (at least implicitly) applying the yardstick of logical norms it would indeed be impossible to know what something illogical is. Orderliness and disorderliness point towards God's law. If God did not control and/or maintain and/or keep and/or sustain logical laws (the creation order for logical thinking), neither obedient nor disobedient (norm-conformative or antinormative) thinking would have been possible. The human subject is the accountable point of reference - in obedience and disobedience. Maintaining the creation order after the fall does not eliminate the normed human freedom of choice. For this reason God's sovereignty and human accountability are not in conflict.

The appeal of God's norming law has exerted its effect throughout the existence of humankind, but it was not acknowledged as such, at least not within the most dominant intellectual traditions. Plato already discovered the constancy of God's law in his response to the Heraclitian emphasis on flux, because if everything changes there would be no steadfast handles for conceptualising to hold on to. The speculative theory of transcendent, eternal and immutable ideas, advanced in Plato's early dialogues (such as Gorgias and Phaido), was made immanent in the thought of Aristotle, where these ideas surfaced as the universal substantial forms of things. In doing this, Aristotle stumbled upon the universal side of individual entities, their orderliness or law-conformity. At the same time, Plato and Aristotle provided the basis for the realistic metaphysics of medieval philosophy in which universals (universalia) were supposed to have a threefold existence, namely, (1) ante rem in God's mind, (2) in re within things (as copies of the ideas in God's mind) and (3) post rem as the universal subjective concepts within the human mind. According to this view, the platonic ideas in God's mind (which therefore exist prior to what we can observe in the world of becoming), are copied into the creatures as their universal substantial forms. These ideas are also appreciated as thoughts or concepts within God's mind. Interestingly, the influence of this metaphysical view is clearly found in reformed theology. For example, during the centenary festivals of the Potchefstroom University for Christian Higher Education held at Potchefstroom in 1969, one of the main 
speakers (a member of the University Council, Dr Postma) defended the view that the task of a Christian university is to think God's thoughts, as they are found in creatures, after him.

\section{Eliminating God's law: The implications of modern Humanism}

The challenge to the reigning medieval metaphysics came from the late Scholastic movement of nominalism, which denied both the universalia ante rem and the universalis in re - that is to say, both God's law for creatures and the orderliness of creatures. But when every 'order for' ('orderdetermination of') is eliminated, factual reality turns into chaos. This happened at a time when, during the Renaissance, modern Humanism emerged in its urge to proclaim human beings as self-determining, as autonomously free. The ideal to become a law-for-oneself stretched itself out beyond human subjectivity, because it embraced also the structureless (chaotic) reality out there. In his discussion of the thought of Descartes, Von Weizsäcker (2002) reveals a penetrating understanding of this orientation:

This state of affairs is characteristic of modernity. It is not the world in which I find myself that guarantees my existence. This guarantee is not lost, for when I recover the world then it is as the object of my self-assured thinking, that is to say, as an object which I can manipulate. ${ }^{2}$ (p. 130-131)

This manipulation of the 'world' soon gave rise to the ideal of logical creation. Truth is no longer seen in terms of the realistic yardstick (as the correspondence of thought and reality-adequatio intellectus et rei), because it merely concerns the compatibility of concepts. Ernst Cassirer (1971:56) captures this stance as follows: 'Truth does not inhere in the things, but belongs to the names and their comparison, as it occurs in statements. ${ }^{3}$ Kant carried this new motive to its extreme rationalistic consequences. ${ }^{4}$

Already in the early development of modern philosophy, nominalism inspired Descartes to view number and all universals as mere 'modes of thought' (Principles of Philosophy, part I, LVII). During the 17th and 18th centuries, this idea was radicalised. Particularly, the procedure followed by Galileo in formulating his famous law of inertia exerted a strong influence on the way in which Kant elaborated this idea in his view of thought categories. In his famous 1638 treatise on 'two new sciences', Galileo used a historically significant thought experiment (see Galilei [1638] 1973). He contemplated

2.In its orginal German: 'Dies ist ein charakteristisch neuzeitlicher Sachverhalt, Nicht die Welt, in der ich mich vorfinde, garantiert mein Dasein. Diese Garantie geh nicht verloren, und wenn ich die Welt wiederfinde, dann als Gegenstand meines selbstgewissen Denkens und darum als Objekt, das ich hantieren kann' (Von Weizsäcker 2002:130-131)

3.In its orginal German: 'Die Wahrheit haftet nicht an den Sachen, sondern an den Namen und an der Vergleichung der Namen, die wir im Satze vollziehen: veritas in dicto, non in re consistit' (cf. De Corpore, part I, ch. 3, paras.7-8, cited by Cassire 1971:56). The similarities with Rorty's position are obvious!

4.If one defines rationalism as a reification of conceptual knowledge (in terms of universal traits) and irrationalism as a reification of what is unique and individual (i. the reification of conction as a reification of what is unique and individual (i.e. the reification of concept-transcending knowledge or idea-knowledge), the it is clear that nominalism displays a hybrid nature, being at oncerationalistic and irrationalistic - rationalistic in respect of the universal concepts within human reason and irrationalistic regarding the strictly individual nature of the world outside the human mind. the movement of a body in motion, on a path extended into the infinite, and then argued that this body will continue its motion on this path indefinitely if nothing impedes its motion (friction, e.g.). Holz (cf. 1975:345-358) argues that the way in which Galileo formulated this principle of inertia strongly influenced Kant. Kant now assigned a remarkable capacity to human understanding. If Galileo can simply formulate a thought experiment on the basis of the spontaneous subjectivity of human thinking and then deduce a natural law from this mere thought experiment - namely the kinematical law of inertia - and subsequently apply it to moving things in nature, then this must entail that there are a priori elements in our knowledge before all experience. What impressed Kant even more is that these a priori elements in the human mind actually make possible our knowledge of reality in the first place.

This prompted Kant to claim that these laws are not derived from nature. Rather, by employing categories of thought, human understanding prescribes them to nature in an a priori way. This embodies what became known as the Copernican turn in modern epistemology, namely ascribing primacy no longer to the object, but to the thinking human subject.

In a somewhat different context, Kant ([1787] 1956:122) wrote about the difficulty involved in this turn, namely how 'subjective conditions of thought can have objective validity, that is, can furnish conditions of the possibility of all knowledge of objects'. Kant advanced the radical humanistic conclusion - the laws of nature are a priori contained in the subjective understanding of the human being:

- The categories are conditions of the possibility of experience and are therefore valid a priori for all objects of experience (Kant [1787] 1956:161).

- The categories are concepts which prescribe laws a priori to appearances and therefore to nature, the sum of all appearances (Kant [1787] 1956:163).

- Understanding creates its laws (a priori) not out of nature, but prescribes them to nature (Kant [1783] 1969:320, §36).

Human understanding is thus promoted to function as the (a priori) formal lawgiver of nature in a universally valid way.

However, soon this position had to suffer from the relativity introduced by emphasising unique historical events. This focus emerged during the early 19th century, along with the rise of historicism. The assumed universally valid construction of reality by the human subject thus eventually became a victim of the relativistic consequences of this historicism. Combined with the so-called linguistic turn (by the end of the 19th century and the beginning of the 20th century) this process opted for a personally or socially constructed world each person or each society constructs its own unique lifeworld. If the emphasis falls upon language, the additional qualification is that every person or society gives its own meaning to the world. The titles of the following books underscore this development: The social construction of reality: A treatise in the sociology of knowledge (Berger \& Luckmann 1969) and Der sinnhafte aufbau der sozialen welt [The meaningful construction of the social world] (Schutz [1932] 1974). 
As a consequence, we can speak about a general shift from concept to meaning, from thought to language. Introduced by Wilhelm Dilthey before the end of the 19th century, this transition is still popular a hundred years later. In a book on Knowledge and Postmodernism: In historical perspective, the combined 'Introduction' says that the most recent spiritual climate is marked by a 'shift' away from 'documentation to interpretation, away from reconstructing a chain of events to exploring their significance ... Using a conceptual shorthand, we could say that meaning has replaced cause as the central focus of attention' (Appleby et al. 1996:1).

This shift, known as the linguistic turn, represents a new epistemic ideal, following the conceptual rationalism of the Enlightenment and the historicism of the 19th century. However, in addition to the relativistic effects of historicism, it explored the ambiguities entailed in the emphasis of linguisticality. Particularly in what is currently known as Postmodernism, the combination of historicism and the linguistic turn gave birth to a reinforced relativism, because linguistic ambiguity and the necessity of constantly changing interpretations were superimposed upon historical relativity.

It found an ally in the neo-Kantian Baden school (Rickert, Weber and Windelband). Although this school started with absolute and timeless values, it soon reverted to a position where factual (societal) reality was stripped from its normativity. This normativity was then transposed into the new broad category of culture, which had to give shelter to norms, values, meanings and symbols. But all the elements placed within the basket of culture were the constructions of human subjects. Throughout this entire process it was not realised that the three successive epistemic ideals of the past three centuries remain bound to underlying universal and constant conditions that make humankind, as such, possible. Logicality, historicity and linguisticality are all universal features conditioning, amongst others, all human beings.

Postmodernism attempts to negate universality, but it does not recognise the implicit universality entailed in such statements of rejection. When, from a postmodern perspective, it is asserted that 'everything is contextual and everything is interpretation', it occurs easily that the implicit universality present in the qualification 'everything' is overlooked. Kreitzer (2007) raises this issue in response to the postmodern strategy of Van Huyssteen aimed at avoiding both foundationalism and relativism (see Van Huyssteen 1999:63): 'Unfortunately, Van Huyssteen does not see the logical contradiction. He "knows" (a universal truth claim) that all knowledge is interpreted merely within a parochial group' (Kreitzer 2007:7). Any (postmodern) statement containing the term 'all' in its negation of universality is selfreferentially incoherent, because what it wants to deny is presupposed by its mode of formulation.

The assertion of historicism that historical change takes place at the cost of constancy continued to plague the postmodern discourse. Plato already realised that change can only be established on the basis of persistence (constancy). This insight was further explored by Galileo and Einstein. The law of inertia formulated by Galileo is based upon the core kinematic meaning of constancy and the same applies to Einstein's special theory of relativity which, in the first place, is a theory of constancy, asserting that all movement is relative to the velocity of light $c$ in a vacuum (see Strauss 2011). We noted earlier that the law of energy constancy reflects the intermodal coherence between the foundational kinematic aspect and the physical aspect. This coherence also shows that change presupposes constancy and this insight supports our critique of Postmodernism with its emphasis on change at the cost of constancy.

\section{Rationality and the task of Christian scholarship}

The idol of a universal reason did not withstand the test of time, for, since ancient Greece, we have witnessed radical differences both within the domain of philosophy and within the special sciences (the natural sciences and the humanities). The multiple ismic orientations and the equally numerous antinomies flowing from them are the result of reifying certain aspects or parts of reality. For this reason, the first task of Christian scholarship is to honour God as Creator and Sustainer of creation and to avoid the apostate urge to find rest in some or another part or aspect of creation which is then elevated to become the exclusive principle of explanation of the whole universe. The challenge is nothing less but pursuing the path of a non-reductionist ontology. It presupposes the distinction between God and creation, as well as a thorough understanding of the distinction between law and subject.

Not only philosophy but also all the academic disciplines have to use a concept of law and subject. Discovering and analysing these laws should be undertaken by using the transcendental-empirical method, which is motivated by the central biblical motive of creation, fall and redemption. This central biblical revelation informs the idea that the creation order makes possible all the variable empirical phenomena that we can experience. The term transcendental here refers to the founding structure of God's creation order, whilst the term empirical appeals to the variable phenomena of our experience in their integral meaning (i.e. not restricted to sensory experience). Since the Renaissance, the motive of logical creation entered the scene and it gave birth to the idea that the world itself has a rational structure. However, from a Christian point of view, one can rather say that the universe is intelligible, but not that it is rational. For example, the Marburg school of neo-Kantianism claimed that our experience of legal relations is made possible by the concept of law, whereas, both our legal experience and concept of law presuppose the ontic (transcendental) structure of the jural aspect. 
In the Mededelingen of July 1950, Dooyeweerd rejects every conception of:

a scriptural philosophy that looks for support in specific Bible texts for intrinsically philosophical and in general scholarly problems and theories. It actually merely boils down to 'positing a few privileged issues' about which the Bible would give explicit statements, while for the rest, where such special texts are not found, one at leisure can continue to fit into a mode of thinking driven by intrinsically un-biblical motives. (p. 3-4)

P. De B. Kock (1973) underscores the same point:

We believe, however, with the philosophy of the cosmonomic idea, that religion (as pre-scientific root-dynamics) provides only orientation and direction to thought and that by it no single scientific problem is brought to a solution. (p. 12)

The transcendental-empirical method has an inherent dynamic openness:

- By virtue of the radical depth of sin, all human insights (also those discovered by applying the transcendentalempirical method) remain provisional, fallible and open to improvement.

- The wealth of human experience is constantly deepened through science and technical advances, implying that every investigation, in the light of new information, can always be developed further, altered and even refuted.

- Therefore, academic disciplines, in accordance with the nature of scholarly reflection, must proceed to the boundaries of the limited human possibilities and, consequently, must always be aware of the limitations and modest about the insights obtained.

The two most important elements necessary for a continued development of the Reformational legacy of Christian scholarship are given in the tasks, (1) to articulate and investigate modal laws and type laws and (2) to investigate the analogical basic concepts and compound concepts employed in every discipline.

Since whatever there is within the universe, in principle, functions within all modal aspects - one can assert that modal laws display an unspecified universality, for they hold for whatever there is. However, the type laws holding for concrete entities and processes are only applicable to a specific type or kind of entities. For this reason their scope is restricted to a limited class of entities, explaining the specified universality discernable in all type laws. Every type law is still universal, in the sense that it holds for all the entities belonging to the type it delineates, but because not everything in the world belongs to this kind, its universality is restricted or specified. The law for being an atom holds for all atoms (its universality), but it does not hold for everything else (not everything is an atom - its specificity).

In addition, it should be noted that the diversity within creation exceeds the limits of logic. Assessing the logical soundness of arguments (their validity) is bound to the logical principles of identity, non-contradiction and the excluded middle. But already the principle of sufficient reason (ground) points beyond logic to the states of affairs in reality for which one has to account in a scholarly way. And once this 'pointing-beyond' is pursued, the ontic principle of the excluded antinomy enters the scene, safe-guarding us from the antinomies involved in every attempt to reduce what is truly irreducible (and 'primitive') to one or another reified perspective. $^{5}$

Rationality can only fulfil its true calling when it accounts for the cohering diversity within reality without becoming a victim of any form of reductionism. This task cannot flourish apart from an ongoing dialogue with all the dominant trends of thought operating within philosophy and the various disciplines, because Christian scholarship constantly has to appreciate what was observed by other trends without surrendering to the possible one-sided and distorted perspectives in which such insights may be 'packaged'. ${ }^{6}$ Indeed, when Koers follows this guiding star it will continue to strengthen its invaluable contribution to the advancement of Christian scholarship - always allowing for a critical interaction with other trends of thought within the contemporary scholarly dispensation.

\section{Acknowledgements Competing interests}

The author declares that he has no financial or personal relationships which may have inappropriately influenced him in writing this article.

\section{References}

Appleby, J., Covington, E., Hoyt, D., Latham, M. \& Sneider, A., 1996, Knowledge and Postmodernism: In historical perspective, Routledge, New York.

Bendall, D.S. (ed.), 1983, Evolution from molecules to men, Cambridge University Press, Cambridge.

Berger, P.L. \& Luckmann, T., 1969, The social construction of reality: A treatise in the sociology of knowledge, Allen Lane, London.

Clouser, R.A. [1991] 2006, The Myth of Religious Neutrality: An Essay on the Hidden Role of Religious Belief in Theories, University of Notre Dame Press, Notre Dame.

Cassirer, E., 1971, Das Erkenntnisproblem in der Philosophie und Wissenschaft der neueren Zeit, vol. 2, 3rd edn., Wissenschaftliche Buchgesellschaft, Darmstadt.

Darwin, C., [1859a] 1968, On the Origin of Species by means of natural selection or the preservation of favoured races in the struggle for life, ed. J.W. Burrow, Penguin Books, Harmondsworth.

Darwin, C. [1859b], On the Origin of Species by means of natural selection or the preservation of favoured races in the struggle for life, viewed 29 Octobe 2005, from http://www.infidels.org/library/historical/charles_darwin/origin of_species/Intro.html

Discovery Institute, 2008, A scientific dissent from Darwinism - FAQ, viewed 12 June 2011, from http://www.dissentfromdarwin.org/faq.php

Dooyeweerd, H., 1950, 'Over het skriftuurlijk karakter van de Wijsbegeerte der Wetsidee [Ábout the scriptural character of the Philosophy of the Law]', Mededelingen $14(1), 2-4$

Galilei, G., [1638] 1973, Unterredungen und mathematische Demonstration über zwe neue Wissenszweige, die Mechanik und die Fallgesetze betreffend [Discussions and mathematical demonstrations concerning two new branches of science, related to mechanics and the law of gravity], Wissenschaftliche Buchgesellschaft, Darmstadt.

Gould, S.J., 1996, Life's grandeur, Vintage (Random House), London.

5.A more elaborate account of these disctinctions and perspectives are found in my work, Philosophy: Discipline of the disciplines (Strauss 2009).

6.Interestingly, the claim made by Stegmüller (1969:314) in respect of scholarlyscientific thinking, namely that one first has to believe in something in order to scientict (2011:41) reports on an archae, recen (2011:41) reports on an archaeological site in Turkey (Gobekli Tepe) which turned the picture of a development from the domestication of plants and animals, agriculture and permanent settlement to religion around by appreciating religion as basic for all the other developments. 
Hawking, S. \& Mlodinow, L., 2010, Why God did not create the universe, BBC News, viewed 16 November 2010, from http://www.bbc.co.uk/news/uk-11161493

Holz, F., 1975, 'Die Bedeutung der Methode Galileis für die Entwicklung der Transzendentalphilosophie Kants [The significance of Galileo's method for the development of the transcendental philosophy of Kant]', Philosophia Naturalis 15, 344-358.

Jevons, F.R., 1964, The biochemical approach to life, George Allen \& Unwin Ltd, London.

Kant, I., [1783] 1969, Prolegomena einer jeden künftigen Metaphysik die als Wissenschaft wird auftreten können II [Prolegomena to any future metaphysics II], Felix Meiner, Hamburg.

Kant, I., [1787] 1956, Kritik der reinen Vernunft B [Critique of pure reason B], 2nd edn., Felix Meiner, Hamburg.

Kock, P. De B., 1973, Christelike Wysbegeerte: Standpunte en Probleme [Christian philosophy: Standpoints and problems], VCHO, Bloemfontein.

Kreitzer, M.R., 2007, 'Towards a biblical philosophy of science', Christianity and Society, XVII (2 - Winter), 6-19.

Lang, L.H., 2003, Without enzyme catalyst, slowest known biological reaction takes 1 trillion years, viewed 22 November 2010, from http://www.unc.edu/news/ archives/may03/enzyme050503.html

Mann, C.C., 2011, 'The dawn of civilization (Every now and then the dawn of civilization is re-enacted on a remote hilltop in southern Turkey)', National Geographic 219(June), 39-58.

New Scientist collective statement, 2004, 'An open letter to the scientific community', New Scientist, 22 May, viewed n.d., from http://www.cosmologystatement.org/
Ritter, J., 1972, 'Fortschritt', in J. Ritter, G. Bien, J. Frese, W. Goerdt, K.M. Kambartel et al. (eds.), Historisches Wörterbuch der Philosophie, vol. 2, pp. 1032-1059, Schwabe \& Co, Basel.

Sarfati, J., 2010, The greatest hoax on Earth? Refuting Dawkins on evolution, Creation Book Publishers, Atlanta.

Schutz, H., [1932] 1974, Der sinnhafte Aufbau der sozialen Welt [The meaningful construction of the social world], Springer Verlag, Frankfurt am Main.

Stegmüller, W., 1969, Metaphysik, Skepsis, Wissenschaft [Metaphysics, skepticism science], 2nd edn., Springer Verlag, Berlin.

Strauss, D.F.M., 2009, Philosophy: Discipline of the disciplines, Paideia Press, Grand Rapids.

Strauss, D.F.M., 2011, 'Relasiebegrippe in die lig van die vraag of Einstein in die eerste plek " $n$ "relatiwiteitsteorie" ontwikkel het [Relation concepts in view of the question if Einstein in the first place developed a "theory of relativity"1', SuidAfrikaanse Tydskrif vir Natuurwetenskap en Tegnologie 30(1), Art. \#28, 8 pages. Afrikaanse Tydskrif vir Natuurwetenskap
$\mathrm{http}: / / \mathrm{dx}$.doi.org/10.4102/satnt.v30i1.28

Van Huyssteen, J.W.V., 1999, The shaping of rationality: Towards interdisciplinarity of theology and science, William B. Eerdmans, Grand Rapids.

Von Bertalanffy, L., 1973, General system theory, Penguin University Books, Harmondsworth.

Von Weizsäcker, C.F., 2002., Große Physiker, Von Aristoteles bis Werner Heisenberg [Great physicists, from Aristotle to Werner Heisenberg], Deutscher Taschenbuch Verlag, Munich. 